\title{
Prostate Cancer cT1 TNM Finding v7
}

National Cancer Institute

\section{Source}

National Cancer Institute. Prostate Cancer CT1 TNM Finding v7. NCI Thesaurus. Code C89210.

Clinically inapparent tumor neither palpable nor visible by imaging. (from AJCC 7th Ed.) 